ANDRZEJ CZYŻEWSKI JOANNA STROŃSKA-ZIEMANN

\title{
Factors of changes in farming in Piła subregion in the view of Agricultural Censuses in 1996, 2002 and 2010
}

Professor Andrzej Czyżewski

Full Professor at the PUEB Poznań University of Economics and Business

Joanna Strońska-Ziemann, PhD Poznań University of Economics and Business

\section{Introduction}

Changes in farming areas were analysed basing on the analysis concerning figures of demography, infrastructure, environment protection, economy, labour market, agriculture and education for all the subregion municipalities which should reflect the changes covering three following Agricultural Censuses in 1996, 2002 and 2010 as well as additional sources (Ferguson, Takane 1997). Since the analysed phenomena are characterised by multidimensions, variety and complexity, to state common factors of development, the factor analysis was used which allows to find hidden interdependencies between the data. This method enabled the identification and comparison of main factors which created the level of subregion's agricultural and farming areas development in the examined years. The analysis was initiated by the selection of variables out of 70 aggregated factors gathered during the research. Since only 32 objects were analysed, the number of variables must have been reduced. For this purpose, a correlation matrix was used 
to choose only those characteristics which ensured an appropriate level of correlation between the variables (Czyżewski, Strońska-Zieman 2016). Input characteristics were expressed in varied measure units and scales, such as absolute numbers, average levels, ratios of intensity, interests, so it was necessary to convert them all to a form that allowed the comparison of characteristics. The different measures were unified by standardization (normalization). It means that the particular level of an individual unit was related to the average level of the whole set. The measure unit was a standard deviation. Eventually, 15 identical variables were chosen for all analysed years. Moreover, there was a significant number of adopted variables, as a result of implementing an exploratory approach, which requires a combination of possibly wide range of data describing analysed issue. According to the researchers, the factor analysis fulfils its purpose only when variables remain in determined, strong relations. Otherwise, factors will be weak and difficult to interpret (Balicki 2009, Megge 1965, Okón 1964, Zakrzewska 1994). To prove the validity of factor analysis use, Kaiser-Meiyer-Olkin (KMO) Test was performed, which measures sampling adequacy for each variable in the model and for the complete model (Czarnecki, Stanny 2011). Additionally, Bartlett's sphericity test was implemented to prove the assumption that the factor analysis could be applied.

Variables were gathered in triad set of sustainable growth target which is one of the foremost aims of the EU strategy. They were divided into typically corresponding components and indirect ones. Within the environmental component there were two variables: ratio of forests and wooded areas to the total area and permanent grassland to all agricultural land. The group of variables regarding economic development covered the average size of agricultural holdings and number of entities registered in REGON (National Official Business Register)/number of inhabitants. However, social component included the percentage of adults with higher education, feminisation ratio, number of pre-schoolers attending kindergartens and the percentage of flats in new investments (newly built apartments) in a total number of inhabited flats. The set of variables describing the environmental and economic factor contained the average share of property and investment expenditures in total expenditures of municipalities, as well as the number of tractors, whereas the group of social-economic factors included the ratio of private to public entities, working-age employment rate, female labour force to total female population, road network density and agricultural holdings producing mainly or solely for sale. 


\section{Determinants of changes}

The successive stage of the analysis was the correlation analysis which was carried out at the significance level of $a=0.05$, and subsequently a deepened examination of 15 chosen variables which allowed to outline initial hypotheses regarding the structure of factors. Results of the analysis are not presented in the paper, however, they indicated significant relations between described variables which made the interpretation of factors ${ }^{1}$ easier in the following stage. The number of factors for further analysis was chosen on the Kaiser criterion which indicated that only the factors with eigenvalues greater than 1 should retain (Panek 2009). Four factors, which altogether explained $68 \%$ of eigen variation, were chosen for tested years. While attributing individual ratios to individual factors it was assumed that the factor can regard those indices which exceeded the sufficient factor loading of 0.7. However, if an individual ratio had a loading greater than 0.7 in case of several factors, it was assigned to the one with the greatest share. The order of variables within a given arrangement depended on the level of factor loading (Czyżewski 1983).

In case of all analysed years, the first factor explained approximately $30 \%$ of a total variance, however, its role increased in 2002 and decreased in 2010. The second factor explained less than $20 \%$ of total variance and its share decreased in 2002 and grew in 2010. Both factors jointly explained almost 50\% of common variation. The third factor, like the second one, in 2002 explained less of a total variance than in 1996, however, it became more significant in 2010. The fourth factor, in examined years, explained a similar scope of common variation ranging from $9 \%$ to $9.4 \%$. Distinguished factors explained the majority of common variation in all years (approx. 68\%).

Table 1. Observed data matrix of factor loadings in 1996, 2002 and 2010

\begin{tabular}{c|c|c|c}
\hline \multicolumn{2}{c}{ Factor } & \multicolumn{3}{c}{ Eigenvalues } \\
\hline & 1996 & 2002 & 2010 \\
\hline F1 & 4.54 & 4.67 & 4.48 \\
\hline F2 & 2.58 & 2.06 & 2.60 \\
\hline
\end{tabular}

1 In case of analysed communality of Piła regions municipalities, the critical value of correlation coefficient at the level of significance $\alpha=0,05$ is 0,51397 . Therefore all $-0,51397 \leq r \leq 0,51397$ can be considered insignificant in view of this paper. 


\begin{tabular}{c|c|c|c}
\hline F3 & 2.01 & 1.78 & 1.89 \\
\hline F4 & 1.35 & 1.35 & 1.18 \\
\hline F1 & \multicolumn{3}{|c}{ \% of Variance } \\
\hline F2 & 30.26 & 31.17 & 29.86 \\
\hline F3 & 17.19 & 11.86 & 17.35 \\
\hline F4 & 13.42 & 13.73 & 12.60 \\
\hline F1 & 9.00 & 9.02 & 9.42 \\
\hline F2 & 30.26 & 31.17 & 29.86 \\
\hline F3 & 47.44 & 43.03 & 47.22 \\
\hline F4 & 60.86 & 56.76 & 59.81 \\
\hline
\end{tabular}

Source: own elaboration based on results of factor analysis of examined observation matrices

Statistical presentation of loadings takes the form of correlation coefficients (positive or negative) between an individual factor and variables. That is the level of factor loadings enables the identification of a system of variables related to given factors.

Table 2. Specification of distinguished factors in 1996, 2002, 2010

\begin{tabular}{|c|c|c|c|}
\hline Factor & 1996 & 2002 & 2010 \\
\hline $\mathrm{F}_{1}$ & \multicolumn{3}{|c|}{$\begin{array}{c}\text { Production limits of agricultural holdings due to resources determinants in Piła } \\
\text { subregion }\end{array}$} \\
\hline $\mathrm{F}_{2}$ & \multicolumn{3}{|c|}{ Social-economic activity in rural areas of Piła subregion } \\
\hline $\mathrm{F}_{3}$ & \multicolumn{3}{|c|}{ Human capital in the labour market in Piła subregion } \\
\hline $\mathrm{F}_{4}$ & \multicolumn{3}{|c|}{$\begin{array}{c}\text { Road network and social infrastructure development in municipalities of Piła } \\
\text { subregion }\end{array}$} \\
\hline
\end{tabular}

Source: own study based on results of factor analysis 
Thus, they are recognised as the reason of correlation found in a given subset (Czyż 1971). Positive loadings inform about a positive influence on a given factor (stimuli) and, in turn, negative loadings inform about the inversely related connection (destimuli). The value of factor loading (Czyżewski 1976) determines the hierarchy of variables within a given set. The factor loading structure for particular factors enables rather unambiguous interpretation. However, it should be noted that there was no possibility to fully unify the factors in all the years of examined period.

\subsection{Factor $F_{1}$ - Production limits of agricultural holdings due to resources determinants in Piła subregion}

The construction of F1 factor, in all analysed years, was based on the set of variables of similar character. Thus, it was described as Production limits of agricultural holdings due to resources determinant in Pita subregion. Due to resources determinants, it was a destimuli. It means that it did not contribute to the development of rural areas, on the contrary, it limited that development. Besides measures directly defining production abilities of agricultural holdings, such as: technical equipment, commodity or acreage, the variables that formed this factor indicated the use of land in examined subregion. Those variables show the dilemma of the land development choice, between the level of anthropogenization of land (arable land, road network infrastructure, number of flats) and preserving natural values (Noteć meadows, forests). They describe a certain attractiveness of the region in terms of settlement, measured, among other things, by infrastructure development (newly built apartments and access to the care of younger children). A stability of the direction of gathered characteristics, in all analysed years, must be stressed. In case of examined region, it is difficult to state whether the character of variables' loadings describing agricultural holdings resulted from a small number of commercial farms in a total number of holdings, which, in turn, led to low technical equipment and disadvantageous average area or on the contrary, the big agricultural holdings, of which share in land use is high, in reality do not contribute to local development.

Among seven characteristics which appeared in the factor's structure in the whole period, three appeared in every single year. In the first analysed period variables were subject to positive changes regarding the influence on rural areas development because the stimuli role, which concerned natural resources, was rising and the roles of variables which did not contribute to that growth and which concerned production abilities of agricultural holdings diminished. It is 
worth determining what could cause the strengthening of variables responsible for subregion development and weakening of those which were not involve in it.

It was established that strong commercial farms characterised by a larger acreage and the level of equipment were a specific antidote to the influence of limits of mainly natural resources. Factor analysis led to an ascertainment that the destimuli character of a factor resulted from a visible polarisation of municipalities in terms of co-existence of large and small agricultural holdings, a lack of social-economic structures in villages after the closure of State Farms (PGR) and historical events in the form of a border shape until 1939 and changes after IIWW and natural conditions bound up with the level of forestry and the existence of Noteć meadows.

Table 3. Production limits of agricultural holdings due to resources determinants in Piła subregion in 1996, 2002 and 2010. Construction of F1 factor

\begin{tabular}{l|c|c|c}
\hline \multicolumn{4}{c}{ Production limits of agricultural holdings due to resources determinants } \\
\hline \multicolumn{1}{c|}{ Year } & 1996 & 2002 & 2010 \\
\hline Share of forests in total area & $\mathbf{0 . 7 9 8 6}$ & $\mathbf{0 . 8 6 8 7}$ & 0.6298 \\
\hline Percentage of pre-schoolers attending kindergartens & 0.5275 & 0.5773 & $(0.1288)$ \\
\hline Share of permanent grassland in total grassland & $(0.0646)$ & $(0.0986)$ & 0.688 \\
\hline $\begin{array}{l}\text { Percentage of flats in newly built buildings of total number } \\
\text { of apartments }\end{array}$ & $(-0.1948)$ & $\mathbf{0 . 7 0 7 5}$ & $(0.1575)$ \\
\hline Average area of total agricultural land & -0.6147 & $(-0.2758)$ & $\mathbf{- 0 . 7 3 8 4}$ \\
\hline Number of tractors & $\mathbf{- 0 . 9 3 9 9}$ & $\mathbf{- 0 . 7 2 8 6}$ & $\mathbf{- 0 . 8 4 3}$ \\
\hline Agricultural holdings producing mainly or solely for sale & $\mathbf{- 0 . 9 1 9 2}$ & $\mathbf{- 0 . 7 7 6 8}$ & $\mathbf{- 0 . 8 3 9}$ \\
\hline
\end{tabular}

Source: based on the results of factor analysis of examined observation matrices in STATISTICA 10.0

\subsection{Factor $F_{2}$ - Social-economic activity in rural areas of Piła subregion}

The factor in all analysed years was a stimuli which means that it consistently contributed to the development of subregion's rural areas. The construction of 
the factor in 1996, 2002 and 2010 is based on the similar set of variables therefore this factor was described as Social-economic activity in rural areas of Pita subregion. The strength of its influence varied in individual years. In the period of 19962002 the share of explanatory value of this factor diminished concerning the common variation. In the following period, it increased (on the contrary to factor $\mathrm{F}_{1}$ ). Due to a similar set of variables which were included in this factor in all the analysed years they were analysed jointly.

Table 4. Social-economic activity in rural areas of Piła subregion in 1996, 2002 i 2010. Construction of $F_{2}$ factor

\begin{tabular}{l|c|c|c}
\hline \multicolumn{4}{c}{ Social-economic activity in rural areas of Piła subregion } \\
\multicolumn{1}{c|}{ Year } & $\mathbf{1 9 9 6}$ & $\mathbf{2 0 0 2}$ & $\mathbf{2 0 1 0}$ \\
\hline Ratio of private to public entities & $\mathbf{0 . 8 3 0 6}$ & $\mathbf{0 . 7 0 9 6}$ & 0.4043 \\
\hline $\begin{array}{l}\text { Number of entities registered in REGON system in } \\
\text { relation to the number of inhabitants }\end{array}$ & $\mathbf{0 . 8 6 4 3}$ & $\mathbf{0 . 9 2 3 1}$ & $\mathbf{0 . 8 3 1 3}$ \\
\hline $\begin{array}{l}\text { Average budgetary incomes of municipality due to the } \\
\text { share in PIT and CIT per 1 inhabitant }\end{array}$ & $\mathbf{0 . 7 8 8 3}$ & 0.1918 & $\mathbf{0 . 7 9 1 9}$ \\
\hline $\begin{array}{l}\text { Percentage of adults with higher education } \\
\text { Percentage of flats in newly built buildings in a total } \\
\text { number of inhabited apartments }\end{array}$ & 0.3504 & 0.4163 & 0.4541 \\
\hline \begin{tabular}{l} 
Feminization coefficient $\left.{ }^{1} \%\right)$ \\
\hline
\end{tabular} & -0.1501 & 0.07099 & $\mathbf{0 . 7 4 0 8}$ \\
\hline
\end{tabular}

Source: based on the results of factor analysis of examined observation matrices in STATISTICA 10.0

The factor was constructed with the variables describing economic activity, i.e. the ratio of private to public entities, the number of entities registered in REGON system in relation to the number of inhabitants and average budgetary incomes of municipality due to the share in PIT and CIT per 1 inhabitant and characteristics defining social activity, i.e. percentage of adults with higher education, percentage of flats in newly built buildings in a total number of inhabited apartments and the feminization coefficient. All variables had a significant, positive influence on the factor which indicated a similar direction of changes. It can be assumed that the growth of social activity in a form of a better education was caused 
by higher incomes of the population and the increase of entrepreneurship in municipalities. It also contributed to the improvement of inhabitants' existence by the opportunity to buy new apartments (except the year 1996).

In all the analysed years, the variable that was most closely related to the distinguished factor, was the one characterising the level of entrepreneurship (number of entities registered in REGON system in relation to the number of inhabitants). Between 1996 and 2002 the strength of the relation grew and despite the fact that it dropped by 2010, the relation was still very strong.

\subsection{Factor $\mathrm{F}_{3}$ - Human capital in the labour market in municipalities of Piła subregion}

Loadings of all variables were positively correlated with a distinguished factor, therefore, in the analysed period it was a stimuli. The factor Human capital in the labour market in the municipalities of Pita subregion in 1996, 2002 and 2010 was determined by a set of similar variables.

Table 5. Human capital in the labour market in municipalities of Piła subregion in 1996, 2002 and 2010. Construction of $F_{3}$ factor

\begin{tabular}{l|c|c|c}
\hline \multicolumn{4}{c}{ Human capital in the labour market in municipalities of Piła subregion } \\
\multicolumn{1}{c|}{ Year } & $\mathbf{1 9 9 6}$ & $\mathbf{2 0 0 2}$ & $\mathbf{2 0 1 0}$ \\
\hline $\begin{array}{l}\text { Percentage of flats in newly built buildings in a total } \\
\text { number of inhabited apartments (1) }\end{array}$ & $\mathbf{0 . 7 9 3 9}$ & 0.0095 & -0.1983 \\
\hline $\begin{array}{l}\text { Labour force, female (\% of total labour force) (2) } \\
\text { Working-age employment rate (3) }\end{array}$ & $\mathbf{0 . 9 0 3 4}$ & $\mathbf{0 . 9 2 4 8}$ & $\mathbf{0 . 9 6 5 7}$ \\
\hline Percentage of adults with higher education (4) & $\mathbf{0 . 3 6 0 0}$ & $\mathbf{0 . 9 3 7 6}$ & $\mathbf{0 . 9 5 6 9}$ \\
\hline
\end{tabular}

Source: based on the results of factor analysis of examined observation matrices in STATISTICA 10.0

In all the year of analysed period (table 5) two variables were strongly related with the factor $(2,3)$. They both concerned the level of employment and they reflected the characteristics of human capital by female professional activity, as well as the level of educational attainment of the population (4). According to adopted assumptions, if the variables appeared in case of several factors, then they were assigned to that factor where they achieved the highest loadings. The 
most significant role in factor's structure fell to a variable describing population professional activity. Every year its significance grew. Also, working-age employment rate gained in strength over the researched period.

\subsection{Factor $F_{4}$ - Road network and social infrastructure development in municipalities of Piła subregion}

Loadings of main variables in this set were positively correlated with the factor, therefore it was determined to be a stimuli. In 1996 and 2002 distinguished factor was mainly described by the variable road network density and in 2010 by the percentage of pre-schoolers attending kindergartens. This presents the aspect of social development of examined subregion. This characteristic was interpreted as the one, in a manner, determining the trust for the institution of a kindergarten. Hence, $\mathrm{F}_{4}$ factor was called Road network and social infrastructure development in municipalities of Piła subregion.

Table 6. Road network and social infrastructure development in municipalities of Piła subregion in 196, 2002 and 2010. Construction of $F_{4}$ factor

\begin{tabular}{c|c|c|c}
\hline \multicolumn{5}{c}{ Road and social infrastructure development in municipalities of Piła subregion } \\
\hline \multicolumn{1}{c|}{ Year } & 1996 & $\mathbf{2 0 0 2}$ & $\mathbf{2 0 1 0}$ \\
\hline Number of pre-schoolers attending kindergartens & -0.0863 & 0.0688 & $\mathbf{0 . 7 2 6 7}$ \\
\hline Road network density & $\mathbf{0 . 8 6 6 6}$ & $\mathbf{0 . 8 3 4 0}$ & 0.4548 \\
\hline $\begin{array}{l}\text { Average budgetary incomes of municipality due to the } \\
\text { share in PIT and CIT per 1 inhabitant }\end{array}$ & 0.0394 & $\mathbf{0 . 6 7 6 5}$ & 0.1613 \\
\hline
\end{tabular}

Source: based on the results of factor analysis of examined observation matrices in STATISTICA 10.0

Applying assumptions adopted in the introduction it must be stated that in 1996 the characteristic of road network density exceeded the threshold of the sufficient factor loading of /0.7/, however, in 2010 it was the percentage of pre-schoolers attending kindergartens. It can be presupposed that in 2002 the factor was additionally formed by the variable - average budgetary incomes of municipality due to the share in taxes (the factor loading close to the threshold), yet, in 2010 the factor along with schooling within pre-school education were also stimulated by the variable regarding road network density which still did 
not reach the critical value. That variable's loading did not change the direction but successively its relation strength diminished (see table 6) which could show the relative significance drop of that characteristic in explaining the common variation of the distinguished factor.

\section{Conclusions}

The conducted factor analysis enabled to indicate and characterise 4 most essential characteristics which had the biggest influence on the total variation of examined observation matrices. In 1996 it was the proximity of forests, the level of entrepreneurship, municipalities' incomes due to taxes, the size of agricultural holdings, development of construction sector and the condition of road network infrastructure that contributed the most to the subregion's development. In this period the number of commercial farms, their technical equipment and share of meadows and pastures lagged behind the economic development. In 2002 the transformation of rural areas was stimulated by the construction sector development, proximity of forests, the level of employment and entrepreneurship, infrastructure development, the share of meadows and pastures in the structure of land use. Alongside this development, the technical equipment of agricultural holdings and the number of commercial farms and their size, fell behind. In 2010 the development of municipalities was stimulated by the level of entrepreneurship, construction sector development, feminisation coefficient and pre-schooling rate, however, all ratios concerning agriculture, i.e. the level of mechanisation, the number of commercial farms and the average size, were of destimuli character.

During the analysed 15 years, the development in Pila subregion was induced by the level of entrepreneurship, labour market situation and natural environment conditions which contributed to the development of suburbanisation processes and expansion of road network and social infrastructure and their derivatives such as the level of incomes, advances in construction industry and the level of pre-schooling. Agriculture acted as a destimuli concerning the development of municipalities of the subregion. However, the significance of those characteristics which in 1996 and 2002 coformed and in 2010 independently formed the factor explaining the biggest part of common variation, must be emphasised. The reason of such position of agriculture in subregion was due to unfavourable economic conditions, especially in the pre-accession period and also natural conditions in the form of dense forestation, the big number of lakes and permanent grassland, 
which also determined polarisation of agricultural holdings in examined municipalities.

\begin{abstract}
Factors of changes in farming in Piła subregion in the view of Agricultural Censuses in 1996, 2002 and 2010

The conducted factor analysis, basing on the outcomes of three successive Agricultural Censuses, selected four factors of changes in agriculture and rural areas of Pila subregion and determined the variation range they accounted for. They were induced by natural environmentconditions, production limits of agricultural holdings, the level of entrepreneurship, labour market situation. Those variables, in turn, contributed to the suburbanisation processes and road network and social infrastructure development, as well as their derivatives, such as, the level of incomes, advances in construction industry and the level of pre-schooling. Agriculture contributed negatively (destimuli) to region's development in analysed years.
\end{abstract}

Key words: agriculture, rural areas, determinants of changes, factor analysis, Pila subregion.

\title{
Streszczenie
}

Czynniki zmian $w$ rolnictwie $i$ na obszarach wiejskich w podregionie pilskim w świetle Powszechnych Spisów Rolnych z lat 1996, 2002 i 2010

W wyniku przeprowadzonej analizy czynnikowej wyników trzech kolejnych Spisów Powszechnych wyłoniono cztery czynniki zmian w rolnictwie i na obszarach wiejskich podregionu pilskiego oraz określono zasób zmienności, za który odpowiadają. Były one indukowane przez uwarunkowania przyrodnicze, ograniczenia produkcyjne gospodarstw rolnych, poziom przedsiębiorczości, sytuację na rynku pracy, które to przyczyniały się do rozwoju procesów suburbanizacji i rozwoju infrastruktury drogowej i społecznej oraz ich w pewnym sensie pochodne, takie jak poziom dochodów, rozwój budownictwa czy poziom skolaryzacji wczesnoszkolnej. Destymulująco na rozwój gmin podregionu wpływało w badanych latach na rolnictwo. 


\section{Słowa}

kluczowe: rolnictwo, obszary wiejskie, determinanty zmian, analiza czynnikowa, podregion pilski.

\section{References}

1. Agricultural Censuses in 1996, 2002 and 2010, Poland, GUS, Warszawa.

2. Balicki A. (2009), Statystyczna analiza wielowymiarowa $i$ jej zastosowania społeczno-ekonomiczne, Wydawnictwo Uniwersytetu Gdańskiego, Gdańsk.

3. Czarnecki A., Stanny M. (2011), Zrównoważony rozwój obszarów wiejskich Zielonych Płuc Polski. Próba analizy empirycznej, Wyd. IRWiR PAN, Warszawa.

4. Czyż T. (1971), Zastosowanie metody analizy czynnikowej do badania ekonomicznej struktury regionalnej polski, Instytut Geografii Polskiej Akademii Nauk, „Prace Geograficzne” No. 92.

5. Czyżewski A. (1983), Ekonomiczne podstawy procesów urbanizacji wsi w Polsce Ludowej, Akademia Ekonomiczna w Poznaniu, Poznań.

6. Czyżewski A. (1976), Miasta wielkopolskie w Polsce Ludowej. Ekonomicznodemograficzne podstawy rozwoju w okresie 1946-1970, Państwowe Wydawnictwo Naukowe, Warszawa-Poznań.

7. Czyżewski A., Strońska-Ziemann J. (2016), Obszary wiejskie w podregionie pilskim przed i po akcesji Polski do UE, Wyd. KPSW w Bydgoszczy, Bydgoszcz.

8. Ferguson G., Takane Y. (1997), Analiza statystyczna w psychologii i pedagogice, PWN, Warszawa.

9. Gospodarstwa rolne w Polsce na tle gospodarstw Unii Europejskiej wpływ WPR (2011-2014), GUS, Warszawa.

10. Megge M. (1965), Nowe dziedziny zastosowania analizy czynnikowej sprawdzanie hipotez dotyczacych rozwoju gospodarczego, BKPZK PAN, Warszawa.

11. Okóń J. (1964), Analiza czynnikowa w psychologii, PWN, Warszawa.

12. Panek T. (2009), Statystyczne metody wielowymiarowej analizy porównawczej, Oficyna Wydawnicza SGH, Warszawa.

13. Zakrzewska M. (1994), Analiza czynnikowa w budowaniu $i$ sprawdzaniu modeli psychologicznych, Wydawnictwo Naukowe UAM, Poznań. 